\title{
Finger Length Ratio (2D:4D) and Aging
}

\author{
Leonid Kalichman', Valery Batsevich², Eugene Kobyliansky ${ }^{3}$ \\ ${ }^{1}$ Department of Physical Therapy, Recanati School for Community Health Professions, Faculty of Health Sciences, Ben-Gurion \\ University of the Negev, Beer Sheva, Israel \\ ${ }^{2}$ Research Institute and Museum of Anthropology, Moscow State University, Moscow, Russia \\ ${ }^{3}$ Department of Anatomy and Anthropology, Tel Aviv University, Tel Aviv, Israel
}

\begin{abstract}
A B S T R A C T
This study aimed to evaluate the association between the index to ring (2D:4D) finger length ratio and aging-related traits (hand osteoarthritis (OA), the osseographic score (OSS), and reproductive period), as well as to assess the heritability of finger length. A Chuvashian population-based sample included 802 males (mean age $46.98 \pm 17.10$ years) and 738 females (mean age 48.65 16.62 years). Age, sex, basic demographics, anthropometric data, reproductive indices (age at menarche, menopausal age, and length of the reproductive period), and $x$-rays of both hands were collected. Finger length ratio was measured on $x$-ray and each hand was visually classified as either type $1-2 D>4 D$; type $2-2 D=4 D$; or type 3 $-2 D<4 D$. Hand $O A$ was defined by the number of affected joints (Kellgren-Lawrence score $\geq 2$ ) and the total of KellgrenLawrence scores (total OA score). OSS is a skeletal biomarker that comprises osteoporotic and OA changes observable on a hands $x$-ray. We calculated the familial correlations and performed a heritability analysis of $2 D: 4 D$ ratio traits in a studied sample. After comparing the OA variables of individuals with different finger length ratio types (after adjustment for age and BMI) significant differences were found only in females between finger ratio types of the right hand in a number of affected joints $(F=3.153, p=0.043)$ and finger ratio types of the left $(F=3.330, p=0.036)$ and right $(F=2.397, p=0.047)$ hands of the total OA score. Females with type 3 ratio had the highest adjusted values of hand OA parameters. Results of one-way ANCOVA for finger length ratio types of the right hand showed a significant difference in OSS ( $d f=2, F=7.569$, $P=0.001)$, after adjustment for age, sex, and BMI. The posthoc comparison showed that individuals with type 3 (2D<4D) ratio showed significantly higher OSS scores than ones with type $1(p=0.012)$ and type $2(p=0.003)$. In an analysis of finger length ratio types of left hand also a significant difference in OSS was found ( $d f=2, F=3.290, P=0.038)$. The posthoc comparison showed that individuals with type 3 ratio showed significantly higher OSS scores than ones with type 2 ( $p=0.33$ ) ratio. We found that a low finger length ratio, a masculine visually evaluated finger length ratio type, was associated with later menarche and a shorter reproductive period. No association was found with menopausal age. Familial correlations of finger length ratio traits showed no significant correlation for spouses, however, parent-offspring $(0.15-0.28, p<0.001)$ and sibling correlations $(0.13-0.38, p<0.009)$ were found significant. Heritability (H2) of visual classification of finger length ratio was 0.36 for the left and 0.28 for the right hand; finger ratio was 0.55 and 0.66 , respectively; the ray ratio was 0.49 and 0.59, respectively, thus indicating the existence of a clear familial aggregation of finger length ratio variation in the Chuvashian pedigrees, which cannot be explained by pure common environmental effects.
\end{abstract}

Key words: hand; finger length ratio; digital ratio; 2D:4D; heritability; aging, osteoarthritis, osseographic score; reproductive period

\section{Introduction}

Numerous studies have suggested that the finger length (2D:4D) ratio is influenced by the balance between androgens and estrogens in the second trimester during embryogenesis. Higher androgen level during this period was found to be associated with a lower finger length ratio $^{1,2}$. A more recent study has suggested that an indi- vidual's finger length ratio may not only be influenced by the degree of exposure to these hormones, but also by their sensitivity to them ${ }^{3}$.

During the last two decades, the finger length ratio has been assessed concerning several physiological processes, psychological aspects ${ }^{2}$, sporting abilities ${ }^{4-6}$ and

Received for publication August 7, 2019 
diverse health conditions $\mathrm{s}^{7,8}$. It was found to be associated with age-related parameters such as bone mineral density $^{9}$ and skeletal biomarkers of biological aging ${ }^{10}$. A low ratio, $2 \mathrm{D}<4 \mathrm{D}$, or more androgenized, finger length ratio/ pattern (Type 3) was significantly associated with osteoarthritis ${ }^{11-16}$. Sigurjonsdottir et al. ${ }^{13}$ found that the type 3 finger ratio was associated with total knee, but not with a total hip replacement. Furthermore, type 3 finger ratio has been reported in individuals with prostate cancer $^{17}$, primary brain tumors ${ }^{18}$, alcohol dependence ${ }^{19}$, Alzheimer's disease in females ${ }^{20}$, and aggression-related injuries in children ${ }^{21}$. Higher (type 1) finger length ratio has also been associated with lethal disease such as breast cancer $^{22,23}$, cervical dysplasia ${ }^{24}$, oral squamous cell carcinoma in males ${ }^{25}$, gastric cancer ${ }^{26}$, Alzheimer's disease in males ${ }^{20}$, coronary heart disease and myocardial infarction ${ }^{27,28}$. The underlying mechanism for such findings is unknown.

Since age at menarche, menopausal age, and duration of the reproductive period affect women's mortality and morbidity ${ }^{29,30}$, an increase in demand for clinical and therapeutic services, and identification of factors associated with these indices in different populations, is clinically and public health-wise very important. Several studies have investigated whether the finger length ratio in women relates to the physiological measures of fertility. It has recently been suggested that the finger length ratio could predict the age of menarche ${ }^{31,32}$, however, Helle ${ }^{33}$ studying a Finnish sample, found no such association. Therefore, we believe that additional studies on different populations are essential to determine the association between the finger length ratio and age at menarche. A recent study ${ }^{34}$ observed an association between right finger length and the difference between right and left finger length $\left(\Delta_{\mathrm{r}-1}\right)$ and age at menopause, with increasing digit ratio associated with an earlier mean age at menopause. To the best of our knowledge, this finding has not as yet been replicated in any other population.

The putative effects of prenatal androgen on finger length can be both genetic and environmental. Clarifying the degree of genetic influences can enhance our understanding of the source of individual differences in finger length and the etiology of the association between finger length and skeletal aging traits.

We carried out a radiographic study on a large population-based sample who had participated in a Chuvashian skeletal aging study investigating different aspects of skeletal aging ${ }^{35}$.

\section{Aims}

This paper is sumarizing the studies that aimed to evaluate the association between the index to ring (2D:4D) finger length ratio and aging-related traits (hand osteoarthritis (OA), the osseographic score (OSS), and reproductive period) as well as to assess the heritability of finger length ratio.

\section{Methods}

\section{Study design: Cross-sectional population-based analyti- cal study}

Sample: The population sampled comprised of native Chuvashians residing in numerous small villages in the Chuvash and Bashkortostan Autonomies of the Russian Federation. The data were gathered during three expeditions undertaken during August/September 1994, May/ June 1999, and September 2002 by the Anuchin Research Institute and Museum of Anthropology, Moscow State University (Russia) and by the Department of Anatomy and Anthropology, Sackler Faculty of Medicine, Tel-Aviv University (Israel). The Chuvashians are believed to have originated from Turkic-Altaic Bulgar tribes who migrated from Northern Caucasus in the $7^{\text {th }}$ to $8^{\text {th }}$ centuries to the western region of the Middle Volga River. They likely represent an amalgamation of Bulgars and the Finno-Ugric tribes who had previously lived in that area and did not adopt Islam ${ }^{36}$. During the 15th and 16th centuries, the Chuvashians emerged as a single nation, comprised of rural Bulgarians. Present-day Chuvashians are genetically related to Mediterraneans and Mid Easterners, scarcely possessing any indications of the Central AsianAltaic gene flow ${ }^{37}$. The population was selected due to the homogeneity of the environment and genetic homogeneity.

The Chuvashians participating in this investigation were randomly chosen volunteers described in detail elsewhere $^{38,39}$. The study cohort included 802 males aged 18-89 years and 738 females aged 18-90 years. Data from $80-90 \%$ of the families (including all family members living in the area at the time of the study) were obtained. Since almost every individual was related to one of the families, we were able to collect data on up to $90 \%$ of the population in each village. All studied individuals were randomly recruited, i.e. regardless of the readings of any of the measured variables. We, therefore, believe that the study sample represented the entire rural population of this area. The Chuvashian population is characterized by a stable family structure with traditional relationships. For generations, the Chuvashians have resided under the same environmental conditions and have not been exposed to an outside genetic flow ${ }^{40}$. A rural population is more homogeneous than an urban population in terms of ethnicity, occupation and physical activity. The study participants shared similar living, economic and professional conditions, with most of the individuals employed in agriculture or other occupations involving physical labor.

The data collected included sex, age, anthropometrical characteristics (height, weight) handedness and occupation. Data obtained from self-completed questionnaires completed during the interview, included sex, age, age at menarche, menopausal age, number of children, and occupation. Menopause was defined as $>12$ months without menstruation (women with less than 12 months of amenorrhea were not included in the present study). Age at last menstruation was considered as menopausal age. To minimize the possible recall bias, the investigators excluded all women who had doubts about their age at menarche or 
age at menopause. Because there were relatively few women above the age of 70 and to reduce recall and survival biases, age was limited to $\leq 70$ years old. Chronic morbidity rates were culled from the participants' medical records and completed during the interview. In the studied sample, there were no users of hormonal replacement therapy or chronic users of steroid medication. All women who had had a hysterectomy before natural menopause, had experienced a post-traumatic event or were diagnosed with rheumatoid or psoriatic arthritis, were excluded from the study. None of the women smoked. After screening, x-ray films of both hands were obtained in addition to the necessary examinations, measurements, and interviews. All procedures were consensual. The studied subjects signed an informed consent form. The entire project was approved by the Helsinki Ethics Committee of Tel-Aviv University.

Body mass index (BMI): BMI was computed as the ratio of weight (in $\mathrm{kg}$ ) divided by height (in meters) squared.

Hand radiographs: Single plain radiographs of both hands were taken in the posteroanterior position with the x-ray source located $60 \mathrm{~cm}$ above using a standard roentgenographic technique, as described in detail by Pavlovsky and Kobyliansky ${ }^{41,42}$. Hands were placed on the same filmcontaining plate to avoid any film or development variation and exposed for 5-10 sec at 100-150 mA without intensifying screens at $50 \mathrm{kV}$. All $\mathrm{x}$-rays were digitized and the radiographic measurements were performed using digital images.

Radiographic measurements of finger ratio: Images were processed using the free UTHSCSA Image Tool software ${ }^{\text {a }}$ We developed a special script using a built-in program language, which enables us to mark the edge of the studied bone by a computerized contour line and subsequently to measure various bone size traits using this contour $^{43}$. The following measurements were made on the index and ring fingers of both hands: (1) from the midpoint of the base of the proximal phalanx to the mid-point of the tip of the distal phalanx; and (2) from the mid-point of the base to the mid-point of the tip of the metacarpal. All measurements were taken by one observer and entered directly into a Microsoft Excel file. If no measurement was possible, the reason was recorded.

Reliability of radiographic measurements: An initial set of x-rays were analyzed to develop a reading protocol for evaluation of finger and metacarpal length. Using this protocol, the reader evaluated 50 x-rays to improve the precision of measurements. Then, another 30 randomly selected x-rays were evaluated twice by the same observer to estimate the reliability of readings. Interclass correlation coefficient (ICC) for fingers measurements ranged between 0.95 (0.88-0.98) and 0.96 (0.089-0.98). Only after the training and reliability evaluation, all x-rays were analyzed in a blinded fashion.

Visual classification of finger ratio type: All x-rays were evaluated by the experienced radiological researcher (L.K.). Each hand was classified according to whether the index finger was longer (type 1), equal to (type 2) or short-

a available at http:// http://compdent.uthscsa.edu/dig/download.html. er than the ring finger (type 3), by visual comparison of the soft tissue outline of the fingertips on the radiograph. As in a previous study ${ }^{44}$, the x-ray was classified into each category using definitions 'definite' or 'probable' according to the certainty of the observer. Each x-ray where the definition was "probable" was assessed by an additional reader and consensus classification was recorded. The inter-reader correlation was high $(\mathrm{k}=0.86)$. The data on actual finger (2D:4D) length ratio in the Chuvashian population was presented in detail in our previous publication ${ }^{45}$.

Osseographic score evaluation: An osseographic score (OSS) was introduced by Kobyliansky and others ${ }^{41}$ to assess the skeletal aging. It based on the radiographic features of the hand, combining both osteoporotic and osteoarthritic changes of the hand bones and joints. Foundations of OSS were originally suggested by Pavlovsky ${ }^{46}$ and have been used in biological age evaluations in population studies $^{41,42,47}$. OSS has been shown to highly correlate with the chronological age in adults of different ethnic groups ${ }^{41,48}$. Genetic factors may also significantly contribute to interindividual differences in biological aging ${ }^{49}$. In variancecomponent genetic analysis, performed in Karasik's study, sex, cohort, height, body mass index, and in women, menopausal status and estrogen use, jointly explained approximately $6 \%$ of the total variance of OSS, whereas genetic factors explained an additional $57 \%$, indicating that most of the variability of OSS was associated with internal factors, providing additional support for the use of OSS as a biomarker of biological aging.

An individual's OSS was determined by the occurrence of the following (Figure 1): (a) Bone proliferations (spurs): 1. apiostoses (tufting of distal phalangeal tuberosity); 2. osteophytes; 3. enthesophytes of juxta-articular area; 4. enthesophytes (subperiosteal expansion) at midshaft; (b) Manifestations of bone porosity: 5 . resorption of trabeculae; 6. development of lacunas (juxta-articular osteopenia); 7. erosion of cortex; (c) sclerosis; 8. enostosis: 9. sclerotic nuclei; 10. subchondral sclerosis; (d) Non-traumatic joint deformities: 11 . narrowing of a joint cavity; 12 . periarticular bone corrosion ${ }^{41,42,50}$. Phalanges of the $2^{\text {nd }}$ to $5^{\text {th }}$ fingers of both hands were examined. The first finger (thumb) does not directly project in a standard X-ray and was therefore not utilized. The presence of a given feature, but not its level of development, was documented for each skeletal aging estimate. The mean value of an overall number of those features for both hands was used as an OSS.

Radiographic assessment of hand OA: The development of OA was evaluated for each of the 14 joints (4 distal interphalangeal, 4 proximal interphalangeal, 5 metacarpophalangeal, and $1^{\text {st }}$ interphalangeal) according to the Kellgren and Lawrence $(\mathrm{K}-\mathrm{L})$ grading scheme, which utilizes photographs from the Atlas of Standard Radiographs ${ }^{51}$. The extent of each of the above-mentioned indexes for each joint, ranged from 0-4. Joints scored as $\mathrm{K}-\mathrm{L} \geq 2$ were considered affected. Each individual was characterized by the total number of affected joints and total OA score (total sum of K-L scores of all 28 joints of both hands). Summing up K-L scores of the hand joints in evaluating hand $\mathrm{OA}$ is common in epidemiological 


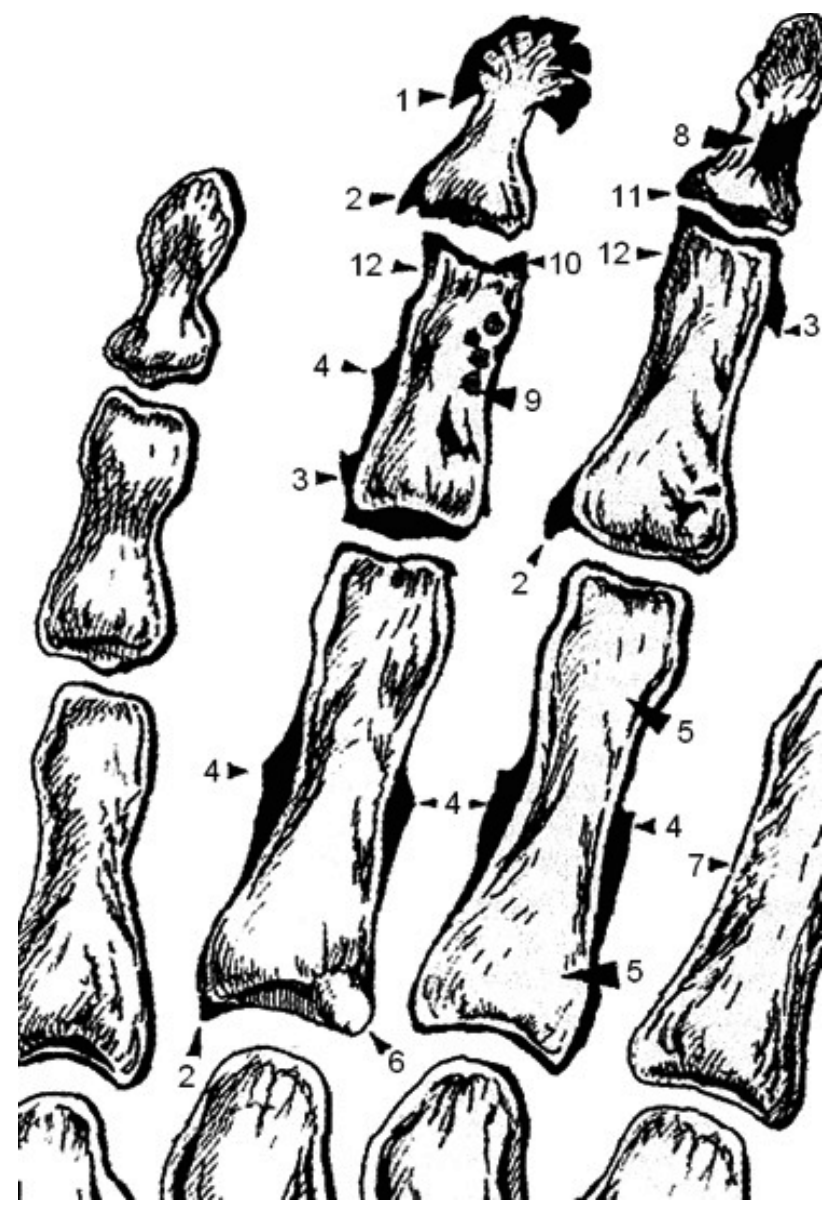

Fig. 1. Diagram of age-changes of hand skeleton assessed by Osseographic Score (OSS) (modified from Pavlovsky and Kobyliansky ${ }^{42}$ and Karasik and others ${ }^{50}$ ). (a) Bone proliferation (spurs): 1. Apiostosis (tufting of distal phalangeal tuberosity); 2. Osteophytes; 3. Enthesophytes of the juxta-articular area; 4. Enthesophytes (subperiosteal expansion) at midshaft; (b) Manifestations of bone porosity: 5. Resorption of trabeculae; 6 . Development of lacuna (juxta-articular osteopenia); 7. Erosion of cortex; (c) Sclerosis: 8. Enostosis: 9. Sclerotic nuclei; 10. Subchondral sclerosis; (d) Non-traumatic joint deformities: 11. Narrowing of the joint cavity; 12. Periarticular bone corrosion.

studies $^{52-54}$. Besides, we divided all subjects into ones with vs. ones without hand $\mathrm{OA}$ (at least one joint with $\mathrm{K}-\mathrm{L} \geq 2$ ).

Reliability of radiographic assessment of hand OA: Initially, two experienced researchers (an orthopedic surgeon and a physician experienced in interpreting x-rays) read a batch of radiographs and decided on the protocol for evaluating the K-L and OSS scores. Ten X-rays were read and then re-read by the investigator to estimate the intra-observer reliability of the readings. All discrepancies were reviewed for systematic errors. This exercise continued until the reliability was high $(\kappa>0.8)$. Thereafter, the investigator read the remainder of the X-rays, still blinded to patient identifiers. Before reading each batch of X-rays, he re-read 5 X-rays that had been previously read, to "cal- ibrate" his readings to a standard. The intra-observer reliability (ICC) for the OSS was $0.92(\mathrm{p}<0.01)$, and for the K-L $0.85(\mathrm{p}<0.01)$.

Statistical analysis: All statistical computations were performed using SPSS 21.0 for Windows (SPSS, Chicago, IL, USA). Mean and standard deviation for age, BMI, and reproductive indices (age at menarche, menopausal age, reproductive period), as well as frequencies of visual classification types, were calculated for each sex separately using descriptive statistics.

Pearson correlation analysis was used to test the association between OSS and age and BMI. To compare OSS between males and females we used one-way ANOVA.

To compare the OSS and OA (number of affected joints and total OA score) variables between individuals with different finger length ratio types (after adjustment for age, sex, and BMI) one-way ANCOVA was used. The analysis was performed separately for finger length ratio types of right and left hands.

Also, to test the association between finger length ratios and hand OA traits we performed two linear regression analyses, with the number of affected joints and total OA score as dependent variables and age, sex, BMI and right and left finger ratios as independent predictors, and one bivariate logistic regression analysis with a dichotomous variable of presence or absence of hand OA (at least one joint with $\mathrm{K}-\mathrm{L} \geq 2$ ) as a dependent variable.

The association between the measured finger length ratio data (phalangeal and metacarpal ratios of both hand), and age at menarche, menopausal age, reproductive period was evaluated using the Person's correlation analysis. Reproductive indices were compared using analysis of variation (ANOVA) between three types of visual classification of the finger length ratios. The relationship between the reproductive indices and the visual classification was examined using a linearity test. To control the potential recall bias for age at menarche ${ }^{55}$, we computed the categorical measures of age at menarche as low (lower 33\%) normal (middle $33 \%$ ) and high (upper $33 \%$ of the distribution). We then built the crosstabs and calculated the $x^{2}$ test to evaluate the association between categorical measures of age at menarche and visual classification of the finger length ratio.

To assess the familial correlations, we used the MAN-7 package for Windows ${ }^{56}$ which computed Pearson's correlations for spouses (Rsp), parent-offspring (Rpo), and siblings (Rsib) in addition to examining the potential genetic effect on the finger length ratio traits. Based on these estimates, the maximal heritability of each trait was evaluated according to Rice's formula ${ }^{57}$ : $\left[\mathrm{h}^{2}=(\mathrm{Rsib}+\mathrm{Rpo})(1+\mathrm{Rsp}) /\right.$ $\left.\left(1+R_{s p}+2 \operatorname{RspRpo}\right)\right]$.

\section{Results}

\section{Description of the study sample}

The study sample (Table 1) included 802 males (mean age $46.98 \pm 17.10$ years) and 738 females (mean age 
TABLE 1

DEMOGRAPHIC AND CLINICAL CHARACTERISTICS

\begin{tabular}{|c|c|c|c|}
\hline & Men $(\mathrm{N}=802)$ & Women $(\mathrm{N}=738)$ & Comparison* \\
\hline Age, mean $\pm \mathrm{SD}$, (years) & $46.98 \pm 17.10$ & $48.65 \pm 16.62$ & $\mathrm{~F}=3.737, \mathrm{p}=0.053$ \\
\hline Body mass index, mean $\pm \mathrm{SD},\left(\mathrm{kg} / \mathrm{m}^{2}\right)$ & $23.19 \pm 3.26$ & $25.16 \pm 4.87$ & $F=86.299, p<0.001$ \\
\hline Number of affected joints, mean \pm SD & $2.78 \pm 4.15$ & $3.24 \pm 4.48$ & $F=4.7279, p=0.039$ \\
\hline Total OA score, mean \pm SD & $20.81 \pm 12.42$ & $22.93 \pm 12.71$ & $\mathrm{~F}=10.811, p=0.001$ \\
\hline Osseographic score (OSS) & $9.45 \pm 7.99$ & $11.13 \pm 9.17$ & $F=14.510, p<0.001$ \\
\hline Age at menarche (years) & & $15.36 \pm 2.02$ & \\
\hline Menopausal age (years) & & $48.77 \pm 4.23$ & \\
\hline Reproductive period (years) & & $32.53 \pm 4.69$ & \\
\hline
\end{tabular}

$\mathrm{SD}=$ standard deviation. *Results of one-way ANOVA $(\mathrm{df}=1)$, statistically significant differences $(\mathrm{p}<0.05)$ marked in bold. $\mathrm{OA}=$ osteoarthritis.

$48.65 \pm 16.62$ years) (age difference between males and females was not significant $\mathrm{p}=0.053)$. The male BMI $\left(23.19 \pm 3.26 \mathrm{~kg} / \mathrm{m}^{2}\right)$ was lower than the female BMI $\left(25.16 \pm 4.87 \mathrm{~kg} / \mathrm{m}^{2}\right)(\mathrm{p}<0.001)$. Females exhibited a significantly higher number of affected joints $(p=0.039)$, total OA score $(p=0.001)$, and OSS $(p<0.001)$. The mean age at menarche for the cohort was $15.36 \pm 2.02$. Menopausal age ranged from $38-57$ years, mean $48.77 \pm 4.23$. In our previous study (Kalichman et al. 2007) performed on the same sample, we found that women whose maturation occurred during or immediately after World War II showed a higher mean age at menarche and a wider dispersion of age at menopause than women born later.

\section{Finger length ratio description}

The distribution of finger length ratio types in the studied sample is shown in Table 2 . No significant differences $(p>0.05)$ in the prevalence of each type of finger ratio in males and females were shown between the right and left hand. However, when comparing the distribution of finger length ratio types between males and females, a significant difference was observed $\left(\mathrm{df}=2, \mathrm{X}^{2}=11.769\right.$, $\mathrm{p}=0.003)$ in the right hand with no significant differences $\left(\mathrm{df}=2, \mathrm{X}^{2}=5.107, \mathrm{p}=0.078\right)$ in the left.

The associations between visual classification and measures finger length ratios in total sample are shown in Table 3. The visual classification was significantly associated with the measured finger length ratio.

TABLE 2

DISTRIBUTION OF FINGER LENGTH RATIO (2D:4D) IN THE STUDIED SAMPLE

\begin{tabular}{lccc}
\hline Finger length ratio & Hand & $\begin{array}{c}\text { Men } \\
\text { N (valid \%) }\end{array}$ & $\begin{array}{c}\text { Women } \\
\text { N (valid \%) }\end{array}$ \\
\hline Type 1 (2D>4D) & Right & $154(20.5 \%)$ & $181(25.2 \%)$ \\
& Left & $175(22.9 \%)$ & $188(26.0 \%)$ \\
Type 2 (2D=4D) & Right & $109(14.5 \%)$ & $132(17.9 \%)$ \\
& Left & $109(14.3 \%)$ & $122(16.9 \%)$ \\
Type 3 $(2 \mathrm{D}<4 \mathrm{D})$ & Right & $490(65.1 \%)$ & $404(56.3 \%)$ \\
& Left & $479(62.8 \%)$ & $412(57.1 \%)$ \\
\hline
\end{tabular}

TABLE 3

\begin{tabular}{cccc} 
ASSOCIATION BETWEEN VISUAL CLASSIFICATION \\
AND THE MEASURED 2D:4D LENGTH RATIOS IN \\
TOTAL SAMPLE \\
$\begin{array}{c}\text { Visual } \\
\text { classification }\end{array}$ & Phalanges & Metacarpals & Ray (Combined) \\
\hline \multicolumn{4}{c}{ Right } \\
Type 1 $(2>4)$ & $0.923 \pm 0.019$ & $1.185 \pm 0.031$ & $1.026 \pm 0.015$ \\
Type 2 $(2=4)$ & $0.915 \pm 0.017$ & $1.179 \pm 0.032$ & $1.019 \pm 0.016$ \\
Type 3 $(2<4)$ & $0.902 \pm 0.021$ & $1.169 \pm 0.031$ & $1.007 \pm 0.017$ \\
P linearity & $<0.001$ & $<0.001$ & $<0.001$ \\
& \multicolumn{4}{c}{ Left } \\
Type 1 $(2>4)$ & $0.926 \pm 0.019$ & $1.177 \pm 0.029$ & $1.025 \pm 0.016$ \\
Type 2 $(2=4)$ & $0.917 \pm 0.017$ & $1.171 \pm 0.030$ & $1.016 \pm 0.014$ \\
Type 3 $(2<4)$ & $0.905 \pm 0.019$ & $1.160 \pm 0.029$ & $1.005 \pm 0.016$ \\
P linearity & $<0.001$ & $<0.001$ & $<0.001$ \\
\hline
\end{tabular}

\section{Association between OSS and finger length ratio}

OSS showed significant association with age $(\mathrm{r}=0.886$, $\mathrm{p}<0.001)$ (Figure 2), BMI $(\mathrm{r}-0.253, \mathrm{P}<0.001)$ and sex $(\mathrm{F}=13.771, \mathrm{p}<0.001)$.

Results of one-way ANCOVA for finger length ratio types of the right hand showed a significant difference in OSS ( $\mathrm{df}=2, \mathrm{~F}=7.569, \mathrm{P}=0.001$ ), after adjustment for age, sex, and BMI. The pairwise comparison of estimated marginal means (adjusted for multiple comparisons using Bonferroni correction) revealed that individuals with type $3(2 \mathrm{D}<4 \mathrm{D})$ ratio showed significantly higher OSS scores than ones with type $1(p=0.012)$ and type 2 $(p=0.003)$. No significant difference in OSS was found between individuals with type 1 and type 2 ratio $(p=1.000)$.

Almost similar results were shown in one-way ANCOVA for finger length ratio types of the left hand. A significant difference in OSS was found ( $\mathrm{d} f=2, \mathrm{~F}=3.559$, $\mathrm{P}=0.029$ ), after adjustment for age, sex, and BMI. The pairwise comparison revealed that individuals with type 


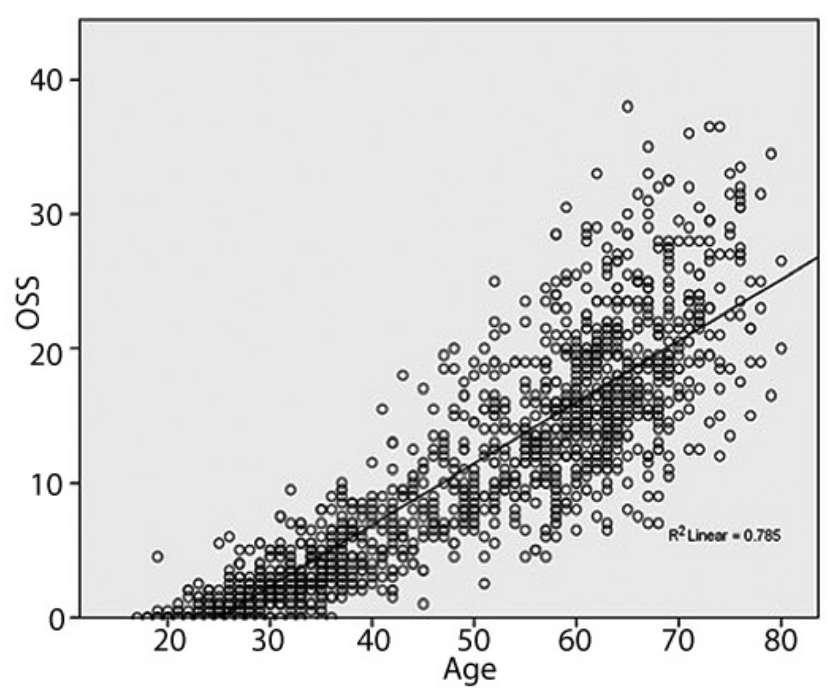

Fig. 2. Scatterplot of association between age and OSS in the Chuvashian population-based sample.

$3(2 \mathrm{D}<4 \mathrm{D})$ ratio showed significantly higher OSS scores than ones with type $2(p=0.026)$ ratio. No significant difference in OSS was found between individuals with type 1 and type 2 ratio $(p=0.303)$ or between individuals with type 1 and type 3 ratio $(\mathrm{p}=0.772)$.

\section{Association between hand $O A$ and finger length ratio}

Distribution of hand OA traits in the studied sample according to the age groups and sex is shown in Table 4. A number of affected joints, total OA score, and proportion of subjects with at least one affected joint, all gradually increased with age, especially after the 5th decade in males and females. Even, as we mentioned before, females had a significantly higher number of affected joints than males (Table 1), in Table 4 one can see that in every age females had a higher number of affected joints than males. Almost all males after age 70 and females after age 60 had at least one joint with hand OA.

Hand OA parameters showed significant positive correlations $(\mathrm{r}=0.653, \mathrm{p}<0.001$ for number of affected joints, and $\mathrm{r}=0.818, \mathrm{p}<0.001$ for total OA score)) with age and BMI $(r=0.189, p<0.001$ for number of affected joints, and $\mathrm{r}=0.259, \mathrm{p}<0.001$ for total OA score).

Results of comparisons of OA variables between individuals with different finger length ratio types (after adjustment for age and BMI) are shown in Table 5. In unadjusted data, the highest values of a number of affected joints and the total OA score was seen in individuals (males and females) with a type $3(2<4)$ finger ratio. However, when adjusted for age and BMI, significant differences were seen only in females between finger ratio types of the right hand in a number of affected joints $(\mathrm{F}=3.153$, $\mathrm{p}=0.043)$ and finger ratio types of the left $(\mathrm{F}=3.330, \mathrm{p}=0$. $036)$ and right $(\mathrm{F}=2.397, \mathrm{p}=0.047)$ hands. Females with a type 3 ratio displayed the highest adjusted values of hand OA parameters.
TABLE 4

DISTRIBUTION OF HAND OA TRAITS IN THE STUDIED SAMPLE ACCORDING TO THE AGE GROUPS AND SEX

\begin{tabular}{|c|c|c|c|c|}
\hline Sex & Age group & $\mathrm{N}$ & $\begin{array}{l}\text { Number of affected } \\
\text { joints (Mean } \pm \text { SD) }\end{array}$ & $\begin{array}{l}\text { Total OA score } \\
\quad(\text { Mean } \pm \text { SD) }\end{array}$ \\
\hline \multirow{6}{*}{$\frac{\stackrel{D}{D}}{\sum}$} & $18-29$ & 162 & $0.17 \pm 0.51$ & $0.05 \pm 0.26$ \\
\hline & $30-39$ & 195 & $0.35 \pm 0.81$ & $0.15 \pm 0.51$ \\
\hline & $40-49$ & 61 & $1.52 \pm 2.16$ & $1.15 \pm 2.42$ \\
\hline & $50-59$ & 105 & $3.45 \pm 3.41$ & $3.88 \pm 3.83$ \\
\hline & $60-69$ & 210 & $5.32 \pm 4.46$ & $6.30 \pm 4.41$ \\
\hline & $70-90$ & 60 & $8.97 \pm 5.48$ & $8.79 \pm 5.61$ \\
\hline \multirow{6}{*}{ 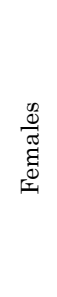 } & $18-29$ & 128 & $8.30 \pm 5.16$ & $8.05 \pm 5.32$ \\
\hline & $30-39$ & 131 & $12.72 \pm 5.81$ & $12.92 \pm 6.37$ \\
\hline & $40-49$ & 86 & $19.70 \pm 7.83$ & $20.49 \pm 8.13$ \\
\hline & $50-59$ & 138 & $26.32 \pm 7.96$ & $28.42 \pm 7.41$ \\
\hline & $60-69$ & 183 & $30.61 \pm 8.67$ & $32.43 \pm 8.28$ \\
\hline & $70-90$ & 62 & $38.01 \pm 10.13$ & $37.92 \pm 10.29$ \\
\hline
\end{tabular}

Linear regression analyses showed that after adjustment for age, sex and BMI, the right finger length ratio showed a significant positive association with total OA score (beta $=0.38, p=0.040$ ) and with a number of affected joints (beta $=0.50, p=0.046$ ). No association was found between the left finger length ratio and hand OA traits. In a logistic regression analysis, no association was found between the dichotomous variable of presence or absence of hand $\mathrm{OA}$ and finger length ratios.

\section{Association between reproductive indices and finger length ratio}

Associations between reproductive indices and radiologically measured finger length ratios are shown in Table 6. As can be seen, only phalangeal ratios of both hands were significantly associated with the length of the reproductive period $(r=0.170, p=0.007$ for right and $r=0.144$, $\mathrm{p}=0.021$ for left hand). To adjust to the potential multiple comparisons, we calculated the Bonferroni correction (Sidak's adjustment) for each group of variables (right and left finger ratios and right and left metacarpal ratios). Because of the high correlation between finger $(r=0.657$, $\mathrm{p}<0.001)$ and metacarpal ratios $(\mathrm{r}=0.638, \mathrm{p}<0.001)$, the alpha level was lowered to 0.028 for finger ratios and to 0.027 for metacarpal ratios. Therefore, the aforementioned correlations remained significant.

Associations between visual classifications of the finger length ratio and reproductive indices are shown in Table 7. A significant association was found between the visual classification of the finger length ratios of both hands and age at menarche $(\mathrm{F}=10.50, \mathrm{p}=0.001$ for right and $\mathrm{F}=20.9$, $\mathrm{p}<0.001$ for left hand), and between the finger length ratio of the left hand and length of reproductive period $(\mathrm{F}=5.82$, $\mathrm{p}=0.016$ ). 
TABLE 5

ASSOCIATION BETWEEN VISUAL CLASSIFICATIONS OF FINGER LENGTH RATIO AND HAND OA PARAMETERS

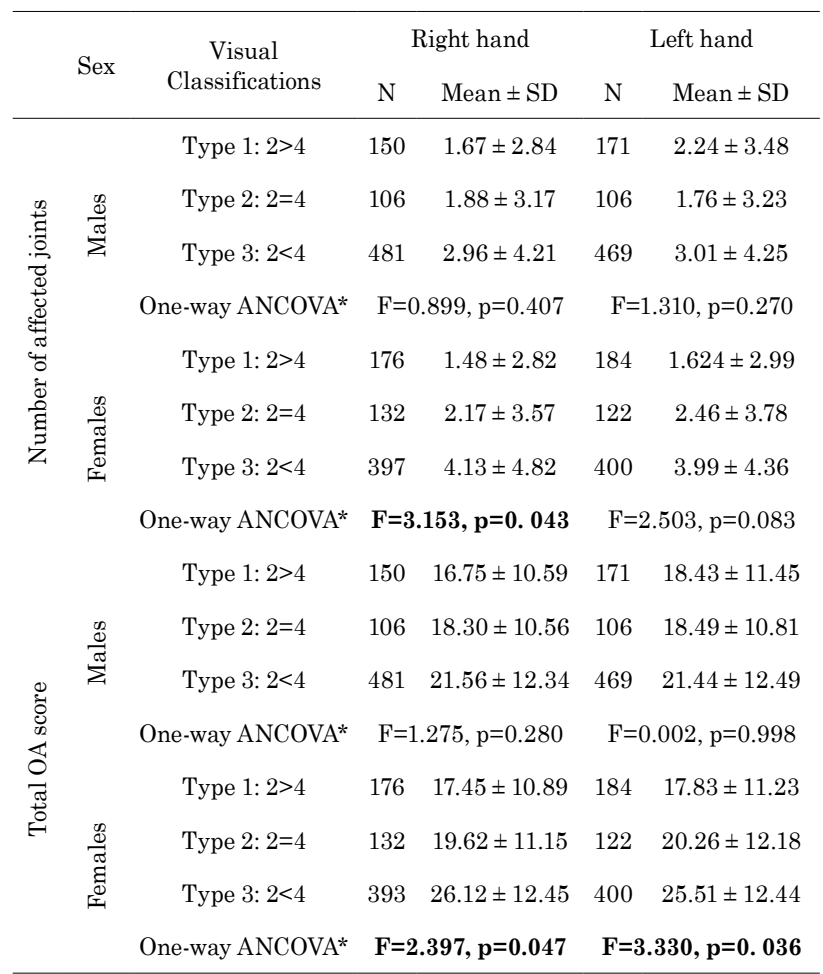

Statistically significant association $(\mathrm{p}<0.05)$ marked in bold; *adjusted for age and BMI.

\section{TABLE 6}

ASSOCIATION (PEARSON'S CORRELATIONS) BETWEEN REPRODUCTIVE INDICES AND RADIOLOGICALLY MEASURED FINGER LENGTH RATIOS

\begin{tabular}{lcccc}
\hline & $\begin{array}{c}\text { Right } \\
\text { phalangeal }\end{array}$ & $\begin{array}{c}\text { Left } \\
\text { phalangeal }\end{array}$ & $\begin{array}{c}\text { Right } \\
\text { metacarpal }\end{array}$ & $\begin{array}{c}\text { Left } \\
\text { metacarpal }\end{array}$ \\
\hline $\begin{array}{l}\text { Age at } \\
\text { menarche }\end{array}$ & $\mathrm{r}=-0.065$ & $\mathrm{r}=-0.044$ & $\mathrm{r}=-0.010$ & $\mathrm{r}=0.046$ \\
Menopausal & $\mathrm{p}=0.119$ & $\mathrm{p}=0.285$ & $\mathrm{p}=0.813$ & $\mathrm{p}=0.266$ \\
age & $\mathrm{r}=0.106$ & $\mathrm{r}=0.081$ & $\mathrm{r}=-0.023$ & $\mathrm{r}=-0.037$ \\
Reproductive & $\mathrm{p}=0.081$ & $\mathrm{p}=0.181$ & $\mathrm{p}=0.705$ & $\mathrm{p}=0.536$ \\
period & $\mathbf{r}=\mathbf{0 . 1 7 0}$ & $\mathbf{r}=\mathbf{0 . 1 4 4}$ & $\mathrm{r}=-0.048$ & $\mathrm{r}=-0.055$ \\
& $\mathbf{p}=\mathbf{0 . 0 0 7}$ & $\mathbf{p}=\mathbf{0 . 0 2 1}$ & $\mathrm{p}=0.441$ & $\mathrm{p}=0.379$ \\
\hline
\end{tabular}

Statistically significant association after the Bonferroni correction (Sidak's adjustment): 0.028 for finger ratios and to 0.027 for metacarpal ratios marked in bold.

\section{Familial correlations and heritability of finger length ratio}

Familial correlations of finger length ratio traits (Table 8) showed no significant correlation for spouses, however, parent-offspring $(0.15-0.28, \mathrm{p}<0.001)$ and sibling correlations $(0.13-0.38, \mathrm{p}<0.009)$ were significant. Moreover, almost all correlations for father-son, father-daughter,
TABLE 7

ASSOCIATION BETWEEN THE VISUAL CLASSIFICATION OF THE FINGER LENGTH RATIO AND REPRODUCTIVE INDICES

\begin{tabular}{|c|c|c|c|c|c|}
\hline & \multirow{2}{*}{$\begin{array}{c}\text { Visual } \\
\text { Classification }\end{array}$} & \multicolumn{2}{|c|}{ Right hand } & \multicolumn{2}{|c|}{ Left hand } \\
\hline & & $\mathrm{N}$ & $\begin{array}{l}\text { Mean age } \\
\quad \pm \mathrm{SD}\end{array}$ & $\mathrm{N}$ & $\begin{array}{l}\text { Mean age } \\
\quad \pm \mathrm{SD}\end{array}$ \\
\hline \multirow{4}{*}{$\begin{array}{l}\text { Age at } \\
\text { menarche }\end{array}$} & Type 1: $2>4$ & 164 & $15.09 \pm 1.85$ & 170 & $14.84 \pm 1.69$ \\
\hline & Type $2: 2=4$ & 116 & $14.90 \pm 1.72$ & 98 & $15.15 \pm 2.19$ \\
\hline & Type $3: 2<4$ & 313 & $15.65 \pm 2.17$ & 327 & $15.67 \pm 2.02$ \\
\hline & $\mathrm{P}$ linearity & \multicolumn{2}{|c|}{$F=10.50, p=0.001$} & \multicolumn{2}{|c|}{$F=20.9, p<0.001$} \\
\hline \multirow{4}{*}{$\begin{array}{l}\text { Menopausal } \\
\text { age }\end{array}$} & Type 1: $2>4$ & 49 & $49.31 \pm 3.86$ & 45 & $49.70 \pm 3.97$ \\
\hline & Type $2: 2=4$ & 37 & $48.31 \pm 4.69$ & 34 & $47.91 \pm 4.53$ \\
\hline & Type 3: $2<4$ & 189 & $48.64 \pm 4.26$ & 197 & $48.62 \pm 4.24$ \\
\hline & P linearity & \multicolumn{2}{|c|}{$\mathrm{F}=0.63, \mathrm{p}=0.430$} & \multicolumn{2}{|c|}{$\mathrm{F}=1.38, \mathrm{p}=0.242$} \\
\hline \multirow{4}{*}{$\begin{array}{l}\text { Reproductive } \\
\text { period }\end{array}$} & Type 1: $2>4$ & 43 & $33.30 \pm 4.36$ & 42 & $34.33 \pm 4.52$ \\
\hline & Type 2: $2=4$ & 37 & $32.58 \pm 4.83$ & 32 & $31.86 \pm 5.24$ \\
\hline & Type $3: 2<4$ & 189 & $32.23 \pm 4.74$ & 183 & $32.16 \pm 4.56$ \\
\hline & $\mathrm{P}$ linearity & \multicolumn{2}{|c|}{$\mathrm{F}=1.77, \mathrm{p}=0.185$} & \multicolumn{2}{|c|}{$\mathrm{F}=5.82, \mathrm{p}=0.016$} \\
\hline
\end{tabular}

Statistically significant association $(\mathrm{p}<0.05)$ marked in bold.

mother-son, mother-daughter pairs, were significant. Father-son and mother-son correlations were slightly stronger than those of father-daughter or mother-daughter pairs. In most cases, the correlations of the right finger length ratio traits were stronger than the left. Heritability $\left(\mathrm{H}^{2}\right)$ of visual classification of finger length ratio was 0.36 for the left hand and 0.28 for right; the finger ratio was 0.55 and 0.66 , respectively and the ray ratio was 0.49 and 0.59 , respectively (Table 9).

\section{Discussion}

OSS

This is a first study that evaluated the association between finger length ratio and skeletal biomarker of biological aging (OSS). Finger length ratio, evaluated in right or left hands, was significantly associated with a skeletal biomarker of biological aging. Our study revealed that individuals with type $3(2 \mathrm{D}<4 \mathrm{D})$ finger length ratio (masculine type) showed significantly higher OSS that ones with type 1 and type 2 . As well, a significant association between type 3 finger ratio and the severity of radiographic hand $\mathrm{OA}$ in females was observed. The association is independent of other established risk factors for OA, such as age and BMI.

The OSS has been shown to correlate highly with chronological age in adults of different ethnic groups ${ }^{58}$, which makes it a suitable biomarker of aging. It was found that OSS strongly governed by genetic factors ${ }^{49,59}$ and as- 
TABLE 8

FAMILIAL CORRELATIONS AND HERITABILITY ESTIMATION OF 2D:4D RATIO TRAITS

\begin{tabular}{|c|c|c|c|c|c|c|c|}
\hline \multirow{2}{*}{$2 \mathrm{D}: 4 \mathrm{D}$} & \multirow{2}{*}{ Familial correlations } & \multicolumn{3}{|c|}{ Right } & \multicolumn{3}{|c|}{ Left } \\
\hline & & No. of pairs & Correlation & $\mathrm{p}$-value & No. of pairs & Correlation & $\mathrm{p}$-value \\
\hline \multirow{7}{*}{ 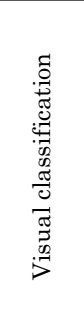 } & Spouses & 297 & -0.012 & 0.958 & 306 & 0.040 & 0.501 \\
\hline & Parents-offspring & 1212 & 0.150 & $<0.001$ & 1231 & 0.162 & $<0.001$ \\
\hline & Father-son & 322 & 0.254 & 0.001 & 320 & 0.226 & 0.001 \\
\hline & Father-daughter & 257 & 0.029 & 0.653 & 262 & 0.137 & 0.029 \\
\hline & Mother-son & 352 & 0.215 & 0.001 & 363 & 0.142 & 0.008 \\
\hline & Mother-daughter & 281 & 0.081 & 0.182 & 286 & 0.137 & 0.021 \\
\hline & Siblings & 397 & 0.132 & 0.009 & 406 & 0.204 & $<0.001$ \\
\hline \multirow{7}{*}{ 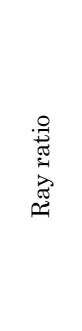 } & Spouses & 278 & -0.013 & 0.981 & 290 & -0.013 & 0.977 \\
\hline & Parents-offspring & 1145 & 0.270 & $<0.001$ & 1167 & 0.246 & $<0.001$ \\
\hline & Father-son & 297 & 0.261 & 0.001 & 298 & 0.264 & 0.001 \\
\hline & Father-daughter & 246 & 0.230 & 0.001 & 248 & 0.227 & 0.001 \\
\hline & Mother-son & 331 & 0.371 & $<0.001$ & 341 & 0.284 & 0.001 \\
\hline & Mother-daughter & 271 & 0.223 & 0.001 & 280 & 0.199 & 0.001 \\
\hline & Siblings & 381 & 0.377 & $<0.001$ & 382 & 0.303 & $<0.001$ \\
\hline \multirow{7}{*}{ 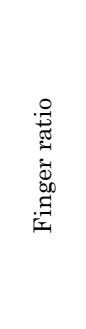 } & Spouses & 290 & 0.050 & 0.398 & 290 & -0.013 & 0.977 \\
\hline & Parents-offspring & 1192 & 0.284 & $<0.001$ & 1167 & 0.246 & $<0.001$ \\
\hline & Father-son & 316 & 0.314 & $<0.001$ & 318 & 0.246 & 0.001 \\
\hline & Father-daughter & 254 & 0.225 & 0.001 & 260 & 0.137 & 0.030 \\
\hline & Mother-son & 346 & 0.340 & $<0.001$ & 361 & 0.313 & $<0.001$ \\
\hline & Mother-daughter & 276 & 0.251 & 0.001 & 285 & 0.235 & 0.001 \\
\hline & Siblings & 392 & 0.305 & $<0.001$ & 382 & 0.303 & $<0.001$ \\
\hline
\end{tabular}

Statistically significant $(\mathrm{p}<0.05)$ correlations marked in bold.

TABLE 9

HERITABILITY ESTIMATION OF VISUAL CLASSIFICATION OF 2D:4D RATIO TRAITS

\begin{tabular}{lcc}
\hline $2 \mathrm{D}: 4 \mathrm{D}$ & \multicolumn{1}{c}{ Right } & Left \\
\hline Visual classification & $(0.28)(0.99) / 0.99+-0.003(0.987)=\mathbf{0 . 2 8 0}$ & $(0.366)(1.04) / 1.04+0.013(1.053)=\mathbf{0 . 3 6 1}$ \\
Ray ratio & $(0.65)(0.99) / 0.99+-0.0097(0.98)=\mathbf{0 . 6 5 7}$ & $(0.548)(0.99) / 0.99+-0.006(0.984)=\mathbf{0 . 5 5 1}$ \\
Finger ratio & $(0.588)(1.05) / 1.05+0.003(1.053)=\mathbf{0 . 5 8 6}$ & $(0.508)(1.08) / 1.08+0.036(1.116)=\mathbf{0 . 4 9 2}$ \\
\hline
\end{tabular}

$\mathrm{H} 2=\left(\mathrm{r}_{\mathrm{sib}}+\mathrm{r}_{\mathrm{po}}\right)\left(1+\mathrm{r}_{\mathrm{sp}}\right) /\left(1+\mathrm{r}_{\mathrm{sp}}+2 \mathrm{r}_{\mathrm{sp}} \mathrm{r}_{\mathrm{po}}\right)$

sociated with some chronic morbidities ${ }^{60}$. Finger length ratio was found to be associated with life-threatening morbidity, including the risks of development of breast ${ }^{22,23}$, gastric $^{26}$, oral ${ }^{25}$ and prostatic ${ }^{17}$ cancers. It was found to be associated with the risk of coronary heart disease in Chinese men ${ }^{27}$ and a predictor of metabolic syndrome ${ }^{61}$. Finger length ratio was also found to be associated with skeletal variables such as bone mineral density ${ }^{9}$ and $\mathrm{OA}$ in various site ${ }^{11-13,16}$. Similarly, the type 3 finger length pattern of index to ring finger ratio, i.e., low ratio or "male" pattern is associated, to a statistically significant degree, with $\mathrm{OA}^{11-14}$. Sigurjonsdottir et al..$^{13}$ found that type 3 finger ratio was associated with total knee replacements but not total hip replacements. The underlying mechanism for such findings is unknown.

\section{Radiographic hand $O A$}

In hand OA, previous studies have shown diverse results. A large population-based Icelandic study ${ }^{13}$ showed no association between type 3 ratio and hand OA. In this study, hand OA was assessed by hand photographs, not x-rays, which may explain the different results. Haugen et al. ${ }^{62}$ in a Framingham community cohort study, found a significant association between a low finger length ratio (similar to a type 3 pattern) and hand OA in females, but not in males. Similarly, another large population-based study from the Netherlands ${ }^{11}$ also found that the type 3 finger length pattern was associated with the prevalence of radiographic hand OA. Thus, the results of our study support the previous findings of an association between hand $\mathrm{OA}$ and type 3 finger length ratio patterns in fe- 
males. Furthermore, this is interesting since we used a different method for defining hand OA.

Theoretically, severe OA could lead to a shortening of the digits and an overestimation of the presence of type 3 finger length patterns ${ }^{11}$. However, in our previous study performed on the same population ${ }^{63}$, no differences were found in the degeneration rate or severity between the second and fourth fingers. de Kruijf et al. ${ }^{11}$ found that when individuals with severe OA in the second finger were excluded, the association between hand OA and the type 3 finger length ratio, remained significant. The type 3 finger length pattern was also found to be associated with $\mathrm{OA}$ in the knees ${ }^{11-14}$ and hips ${ }^{14}$.

One of the possible explanations for the association between type 3 finger ratio and skeletal aging is via hormonal mechanism ${ }^{64}$. Estrogen, in particular, has a complex and possibly protective relationship with the development of $\mathrm{OA}^{65}$. An association of type 3 finger length ratio with hand $\mathrm{OA}$, that not influenced by weight-bearing ${ }^{11}$ supports this theory. Testosterone also may be involved in the etiology of $\mathrm{OA}^{66}$. Both estrogen and testosterone are also known for their role in bone metabolism ${ }^{67,68}$. However, current evidence does not suggest that the finger length ratio is associated with hormonal levels in adults ${ }^{69}$, but more subtle mechanisms may be operating. Further studies are warranted to understand the mechanism of the association between finger length ratio, especially type 3 and age-related skeletal traits, such as OSS and OA.

\section{Reproductive period}

We found evidence of a positive association between the radiologically measured finger length ratio of both hands and length of the reproductive period. High, more femaletype finger length ratios were associated with a longer reproductive period. When visual classification was used, we found the evidence that strengthened our previous findings. Women with type 3 finger length ratio of both hands presented with a significantly higher age at menarche and lower (only for the left-hand ratio) length of the reproductive period. This is in accord with previous studies performed on 206 American healthy female college students $^{31}$ and in 70,658 white women from different countries $^{32}$, but contradicts the results of a Finnish study of 282 post-reproductive women ${ }^{33}$.

\section{Familial correlations and heritability}

Our results revealed the existence of a clear familial aggregation of finger length ratio variations in the Chuvashian pedigrees, which cannot be explained by pure common environmental effects. Our familial correlation results are in accord with previous familial study ${ }^{70}$, twin studies $^{71-73}$, a population-based study ${ }^{74}$, and even a study of rhesus macaques ${ }^{75}$.

The heritability estimates from this study were similar to the results found in a classic study of an Indian sample ${ }^{76}$ which found a weighted average of $\mathrm{H}^{2}=57 \%$. They are also in accord with the results obtained from an Austrian family-based study ${ }^{74}$ which found $\mathrm{H}^{2}=57 \%$ for the right hand and $\mathrm{H}^{2}=48 \%$ for the left. Manning et al..$^{77}$ in a family-based study of 95 families recruited via the National Autistic Society in the UK, showed similar results of $\mathrm{H}^{2}=58 \%$. Twin studies found slightly higher estimates of $\mathrm{H}^{2}$. Furthermore, Voracek and Dressler ${ }^{71}$, in a study of 20 female and 14 male monozygotic twins, found $\mathrm{H}^{2}=62 \%$. Paul et al. ${ }^{72}$ in a large study of 456 female twins from the St. Thomas' Adult Twin Registry, found $\mathrm{H}^{2}=66 \%$ (95\% CI:50-78). Similar results were found in twin studies of Gobrogge et al. ${ }^{78}$ and Medland and Loehlin ${ }^{79}$. Even in a study of rhesus macaques ${ }^{75}$, authors found $\mathrm{H}^{2}=62 \%$ for the right and $\mathrm{H}^{2}=42 \%$ for the left hand, suggesting that the strength of heritability of finger length ratio may generalize across taxa. Two other reports ${ }^{80,81}$ found a high heritability $\left(\mathrm{H}^{2}=\right.$ $70-80 \%$ ) of finger length ratio in zebrafish finches.

\section{Finger length ratio and aging (conclusion)}

The present study found that the finger length ratio is associated with aging-related traits. Type 3 (masculine finger length ratio type) of finger length pattern showed significantly higher OSS that those with type 1 and type 2 . The finger length ratio was also found to be associated with hand OA parameters. Females with a type 3 finger length pattern showed significantly higher hand OA values than types 1 and 2. Low 2D:4D ratio and type 3 finger length ratio was associated with later menarche and a shorter reproductive period. No association was found with menopausal age. These findings are supported by the results of other studies. In a recent large cross-national study ${ }^{82}$, the authors found that type 3 finger ratio values (in relation to the mean male and female finger length ratio), were found in countries with lower life expectancies of males (in relation to the male and female mean). This observation supports the assumption that prenatal sex hormone priming entails long-lasting, possibly lifelong effects on sex-specific death risks. The authors suggested that a lower (prenatally more androgenized or type 3) finger length ratio might be sex-specifically associated with a lower life expectancy.

On the other hand, there is a growing body of reports on comparisons of mean finger length ratio per nation and mortality-related variables, such as gross domestic products, risk-taking, consumption of tobacco and alcohol ${ }^{83-85}$, and for various cancers ${ }^{86}$. Nations with a high mean finger length ratio (more feminine type) consume more tobacco per capita than nations with low mean finger ratio ${ }^{84}$. Smoking is also linked to early-age myocardial infarction in men and type 1 finger length ratio ${ }^{87}$. Similarly, earlyage breast cancer was found to be associated with a type 1 finger length ratio ${ }^{88}$. Using the $\mathrm{BBC}$ online national digit ratio means Manning \& Fink ${ }^{86}$ reported significant positive correlations of finger length ratio means with agestandardized disability-adjusted life years for five cancers (stomach, liver, lung, cervix \& leukemias) with the only one showing a negative correlation (prostate). To conclude the aforementioned, the type 1 finger length ratio was found to be related to important morbidities that have the potential of shortening the life span. In our recent study ${ }^{89}$ we found that the finger length ratio pattern in longevity 
populations (Abkhazians, Azerbaijanis, and Georgians) differs from that of non-longevity populations (Russians). In longevity samples, the prevalence of type 1 ratio was lower and the prevalence of type 3 ratio was higher versus the non-longevity sample. A similar type of difference was seen in the longevity and non-longevity samples belonging to one ethnic group, the Abkhazians. We believe that further research should focus on exploring the biological mechanism behind the association between finger length ratio and aging.

\section{R E F E R E N C E S}

1. LUTCHMAYA S, BARON-COHEN S, RAGGATT, P. KNICKMEYER, R. MANNING, JT, Early Hum Dev, 77 (2004) 23. - 2. PUTZ D, GAULIN S, SPORTER R, MCBURNEY D, Evolution and Human Behavior, 25 (2004) 182. - 3. KNICKMEYER RC, WOOLSON S, HAMER RM, KONNEKER T, GILMORE JH, Hormones and behavior, 60 (2011) 256. - 4. MANNING JT, TAYLOR RP, Evolution and Human Behavior, 22 (2001) 61. - 5. PAUL SN, KATO BS, HUNKIN JL, VIVEKANANDAN S, SPECTOR, TD, Br J Sports Med, 40 (2006) 981. - 6. HONEKOPP JJTM, MULLER C, Hormones and behavior, 49 (2006) 545. - 7. MANNING JT, BUNDRED, PE, Med Hypotheses, 54 (2000) 855. - 8. VEHMAS T, SOLOVIEVA S, LEINO-ARJAS P, J Negat Results Biomed, 5 (2006) 12. - 9. ARAZI H, EGHBALI E, SAEEDI T, MOGHADAM R, J Clin Densitom 19 (2016) 382. — 10. KALICHMAN L, BATSEVICH V, KOBYLIANSKY E, Anthropologischer Anzeiger Bericht uber die biologisch-anthropologische Literatur, 74 (2017) 221. - 11. DE KRUIJF M, KERKHOF HJ, PETERS MJ, BIERMA-ZEINSTRA S, HOFMAN A, Arthritis Care Res, 66 (2014) 1337. — 12. FERRARO B, WILDER FV, LEAVERTON PE, Osteoarthritis and cartilage, 18 (2010) 354. - 13. SIGURJONSDOTTIR K, BJORGULFSSON TM, ASPELUND T, EIRIKSDOTTIR G, SIGURDSSON S, INGVARSSON T, HARRIS TB, LAUNER L, GUDNASON V, JONSSON H, BMC Musculoskelet Disord, 14 (2013) 112. - 14. ZHANG W, ROBERTSON J, DOHERTY S, LIU JJ, MACIEWICZ RA, MUIR KR, DOHERTY M, Arthritis Rheum, 58 (2008) 137. - 15. KALICHMAN L, BATSEVICH V, KOBYLIANSKY E, Rheumatology Int, 38 (2018) 865. - 16. HUSSAIN SM, WANG Y, MULLER DC, WLUKA AE, GILES GG MANNING JT, GRAVES S, CICUTTINI FM, Rheumatology, 53 (2014) 1200. - 17. MENDES PH, MARTELLI DR, DE MELO COSTA S, GONCALVES E, MACEDO CP, SILVEIRA MF, MARTELLI JUNIOR H, Prostate Cancer and Prostatic Diseases, 19 (2016) 107. - 18. BUNEVICIUS A, TAMASAUSKAS S, DELTUVA VP, TAMASAUSKAS A, SLIAUZYS A, BUNEVICIUS R, Early Hum Dev, 103 (2016) 205. - 19. LENZ B, MUHLE C, BRAUN B, WEINLAND C, BOUNA-PYRROU P, BEHRENS J, KUBIS S, MIKOLAICZIK K, MUSCHLER MR, SAIGALI S, SIBACH M, TANOVSKA P, HUBER SE, HOPPE U, EICHLER A, HEINRICH H, MOLL GH, ENGEL A, GOECKE TW, BECKMANN MW, FASCHING PA, MULLER CP, KORNHUBER J, Acta Psychiatrica Scandinavica, 136 (2017) 96. - 20. VLADEANU M, GIUFFRIDA O, BOURNE VJ, Cognitive and Behavioral Neurology, 27 (2014) 102. - 21. O'BRIAIN DE, DAWSON PH, KELLY JC, CONNOLLY P, Irish Journal of Medical Science, 186 (2017) 441. - 22. HONG L, ZHAN-BING M, ZHI-YUN S, XIAO-XIA S, JUN-LI Z, ZHENG-HAO H, Am J Hum Biol, 26 (2014) 562. - 23. MULLER DC, BAGLIETTO L, MANNING JT, MCLEAN C, HOPPER JL, ENGLISH DR, GILES GG, SEVERI G, Br J Cancer, 107 (2012) 1631. - 24. BRABIN L, ROBERTS SA, FARZANEH F, FAIRBROTHER E, KITCHENER HC, Am J Hum Biol, 20 (2008) 337. — 25. NICOLAS HOPP R, JORGE J, Am J Hum Biol, 23 (2011) 423. — 26. NICOLAS HOPP R, DE SOUZA LIMA NC, FILHO JL, FILHO MS, LIMA CS, JORGE J, Early Hum Dev, 89 (2013) 327. — 27. LU H, MA Z, ZHAO J, HUO Z, Early Hum Dev, 91 (2015) 417. — 28. KYRIAKIDIS I, PAPAIOANNIDOU P, PANTELIDOU V, KALLES V, GEMITZIS K, Gender medicine, 7 (2010) 628. - 29. CUI R, ISO H, TOYOSHIMA H, DATE C, YAMAMOTO A, KIKUCHI S, KONDO T, WATANABE Y, KOIZUMI A, INABA Y, TAMAKOSHI A, J Epidemiol 16 (2006) 177. — 30. OSEIHYIAMAN D, SATOSHI T, UEJI M, HIDETO T, KANO K, Am J Epidemiol, 148 (1998) 1055. - 31. MATCHOCK RL, Am J Hum Biol, 20 (2008) 487. - 32. MANNING JT, FINK B, Am J Hum Biol, 23 (2011) 527. — 33. HELLE S, Am J Hum Biol, 22 (2010) 418. - 34. MULLER DC, BAGLIETTO L, MANNING JT, MCLEAN C, HOPPER JL, ENGLISH DR, GILES GG, SEVERI G, Br J Cancer, 107 (2012) 1631. - 35. KALICHMAN L, MALKIN I, LIVSHITS G, KOBYLIANSKY E, Joint
Bone Spine, 73 (2006) 406. - 36. TISCHKOV VA (Ed), Encyclopedia of the Peoples of Russia. (Great Russian Encyclopedia Publ. House, Moscow, 1994). - 37. ARNAIZ-VILLENA A, MARTINEZ-LASO J, MOSCOSO J, LIVSHITS G, ZAMORA J, GOMEZ-CASADO E, SILVERA-REDONDO C, MELVIN K, CRAWFORD MH, Hum Biol, 75 (2003) 375. — 38. KALICHMAN L, COHEN Z, KOBYLIANSKY E, LIVSHITS G, Am J Hum Biol, 14 (2002) 380. - 39. KALICHMAN L, LIVSHITS G, KOBYLIANSKY E, Am J Hum Biol, 18 (2006) 350. — 40. EL'CHINOVA GI, ZNICHENKO RA, GINTER EK, Genetika, 39 (2003) 562. - 41. KOBYLIANSKY E, LIVSHITS G, PAVLOVSKY O, Hum Biol, 67 (1995) 87. — 42. PAVLOVSKY O, KOBYLIANSKY E, Population Biology of Human Aging (Angelo Pontecorboli Editore: Firenze, 1997). - 43. KALICHMAN L, MALKIN I, SEIBEL MJ, KOBYLIANSKY E, LIVSHITS G, Homo, 59 (2008) 301. - 44. ROBERTSON J, ZHANG W, LIU JJ, MUIR KR, MACIEWICZ RA, DOHERTY M, J Anat, 212 (2008) 42. - 45. KALICHMAN L, ZORINA D, BATSEVICH V, KOBYLIANSKY E, Homo, 64 (2013) 233. - 46. PAVLOVSKY O, Methods of osseographic studies of the bone. In: PAVLOVSKY, O (Ed): Morpho-physiological researches in anthropology (MGU Publishing House: Moscow, 1981). - 47. LIVSHITS G, VAINDER M, PAVLOVSKY O, KOBYLIANSKY E, Hum Biol, 68 (1996) 293. - 48. KARASIK D, OTREMSKI I, BARACH I, YAKOVENKO K, BATSEVICH V, PAVLOVSKY O, KOBYLIANSKY E, LIVSHITS G, Am J Hum Biol, 11 (1999) 31. — 49. KARASIK D, HANNAN MT, CUPPLES LA, FELSON DT, KIEL DP, J Gerontol A Biol Sci Med Sci, 59 (2004) 218. - 50. KARASIK D, DEMISSIE S, CUPPLES LA, KIEL DP, J Gerontol A Biol Sci Med Sci, 60 (2005) 574. - 51. KELLGREN J, LAWRENCE J, Atlas of standard radiographs: The epidemiology of chronic rheumatism (Blackwell Scientific Publications: Oxford, 1963) - 52. CAULEY JA, KWOH CK, EGELAND G, NEVITT MC, COOPERSTEIN L, ROHAY J, TOWERS A, GUTAI JP, The Journal of Rheumatology, 20 (1993) 1170. - 53. DEMISSIE S, CUPPLES LA, MYERS R, ALIABADI P, LEVY D, FELSON DT, Arthritis Rheum, 46 (2002) 946. - 54. DOMINICK KL, JORDAN JM, RENNER JB, KRAUS VB, Arthritis Rheum, 52 (2005) 1424. - 55. COOPER R, BLELL M, HARDY R, BLACK S, POLLARD TM, WADSWORTH ME, PEARCE MS, KUH D, J Epidemiol Community Health, 60 (2006) 993. - 56. MALKIN I, GINSBURG E, Program package for pedigree analysis (version MAN-2009) (Sackler Faculty of Medicine, Tel Aviv University, Tel Aviv, 2009). - 57. RICE T, DESPRES JP, DAW EW, GAGNON J, BORECKI IB, PERUSSE L, LEON AS, SKINNER JS, WILMORE JH, RAO DC, BOUCHARD C, Int J Obes 21, (1997) 1024. - 58. KALICHMAN L, MALKIN I, KOBYLIANSKY E, Osseographic score as a biomarker of biological aging. (EAA-European Anthropological Association, Biennial Book 2008). - 59. MALKIN I, KALICHMAN L, KOBYLIANSKY E, Biogerontology 8 (2007) 627. — 60. KALICHMAN L, LIVSHITS G, KOBYLIANSKY E, Hum Biol, 78 (2006) 77. - 61. OYEYEMI BF, IYIOLA OA, OYEYEMI AW, ORICHA KA, ANIFOWOSHE AT, ALAMUKII NA, J Res Med Sci, 19 (2014) 234. - 62. HAUGEN IK, NIU J, ALIABADI P, FELSON DT, ENGLUND M, Arthritis Rheum, 63 (2011) 2284. - 63. KALICHMAN L, KOBYLIANSKY E, LIVSHITS G, Joint Bone Spine, 73 (2006) 72. - 64. LINN S, MURTAUGH B, CASEY E, PM \& R, 4 Supp (2012) S169. — 65. TANAMAS SK, WIJETHILAKE P, WLUKA AE, DAVIES-TUCK ML, URQUHART DM, WANG Y, CICUTTINI FM, Maturitas, 69 (2011) 141. - 66. JIN X, WANG BH, WANG X, ANTONY B, ZHU Z, HAN W, CICUTTINI F, WLUKA AE, WINZENBERG T, BLIZZARD L, JONES G, DING C, Osteoarthritis Cartilage, 25 (2017) 1100. - 67. RIGGS BL, J Clin Invest, 106 (2000) 1203. - 68. TUCK SP, FRANCIS RM, Front Horm Res, 37 (2009) 123. - 69. MULLER DC, GILES GG, BASSETT J, MORRIS HA, MANNING JT, HOPPER JL, ENGLISH DR, EVERI G, Reprod Biol Endocrinol, 9 (2011) 57. - 70. RICHARDS G, BELLIN W, DAVIES W, Early Hum Dev, 112 (2017) 14. - 71. VORACEK M, DRESSLER SG, 
Psychological reports 100 (2007) 115. - 72. PAUL SN, KATO BS, CHERKAS LF, ANDREW T, SPECTOR TD, Twin Res Hum Genet, 9 (2006) 215. - 73. HIRAISHI K, SASAKI S, SHIKISHIMA C, ANDO J, Archives of Sexual Behavior, 41 (2012) 711. - 74. VORACEK M, DRESSLER SG, Am J Phys Anthrop, 140 (2009) 376. - 75. NELSON E, VORACEK M, Primates; Journal of Primatology 51 (2010) 1. - 76. RAMESH A, MURTY JS, Ann Hum Biol, 4 (1977) 479. - 77. MANNING JT, BARONCOHEN S, WHEELWRIGHT S, SANDERS G, Developmental Medicine \& Child Neurology, 43 (2001) 160. - 78. GOBROGGE KL, BREEDLOVE SM, KLUMP KL, Archives of Sexual Behavior, 37 (2008) 112. - 79. MEDLAND SE, LOEHLIN JC, Twin Res Hum Genet, 11 (2008) 335. - 80. FORSTMEIER W, ROCHESTER J, MILLAM JR, General and Comparative Endocrinology, 156 (2008) 379. - 81. FORSTMEIER W,
Proc Biol Sci, 272 (2005) 2641. — 82. LENZ B, KORNHUBER J, Journal of Neural Transmission, 125 (2018) 239. - 83. MANNING JT, FINK B, Personality and Individual Differences, 51 (2011) 387. - 84. MANNING JT, FINK B, Personality and Individual Differences, 50 (2011) 344. — 85. MANNING JT, FINK B, TRIVERS R, Evolutionary Psychology 12 (2014) 757. - 86. MANNING JT, FINK B, Digit Ratio. In: SHACKELFORD TK, WEEKES-SHACKELFORD VA (Eds): Encyclopedia of Evolutionary Psychological Science (Springer International Publishing, 2018). - 87. MANNING JT, BUNDRED PE, KASIELSKA-TROJAN A, SMITHSTRANEY T, MASON L, Early Hum Dev, 133 (2019) 18. - 88. MANNING JT, LEINSTER SJ, The Breast 10 (2001) 355. - 89. KALICHMAN L, BATSEVICH V, KOBYLIANSKY E, Am J Hum Biol, 31 (2019) e23212.

\section{Kalichman}

Department of Physical Therapy, Recanati School for Community Health Professions, Faculty of Health Sciences, Ben-Gurion University of the Negev, P.O.B. 653 Beer Sheva 84105, Israel.

e-mail:kleonid@bgu.ac.il

\section{INDEKS DULJINE PRSTIJU (2D: 4D) I STARENJE}

\section{S A Ž E T A K}

Ovo istraživanje imalo je za cilj procijeniti povezanost između omjera duljine kažiprsta i prstenjaka (2D: 4D) i pokazatelja starenja (osteoartritis šake (OA), oseografski rezultat (OSS) i reproduktivno razdoblje), kao i procijeniti nasljednost duljine prsta. U uzorku populacije iz Čuvašije obuhvaćeno je 802 muškarca (prosječna dob 46,98 $\pm 17,10$ godina) i 738 žena (prosječna dob 48,65 $\pm 16,62$ godine). Prikupljeni su podaci o dobi, spolu, osnovna demografija, antropometrijski podaci, reproduktivni indeksi (dob u menarhi, starost menopauze i duljina reproduktivnog razdoblja) i rendgenske snimke obje ruke. Omjer duljine prstiju izmjeren je na rendgenu i svaka ruka vizualno je klasificirana kao tip 1 - 2D> 4D; tip 2 - 2D = 4D; ili 3 - 2D <4D. Osteoartritis šake OA definiran je brojem zahvaćenih zglobova (Kellgren-Lawrence-ova klasifikacija $\geq 2$ ) i ukupnim vrijednostima Kellgren-Lawrence-ove ljestvice (ukupni OA-rezultat). OSS je skeletni biomarker koji sadrži osteoporotične i OA promjene koje se mogu primijetiti na rendgenu ruke. Izračunali smo obiteljske korelacije i izvršili analizu nasljednosti 2D: 4D indeksa u ispitivanom uzorku. Nakon usporedbe OA varijabli pojedinaca s različitim tipovima omjera duljine prstiju (nakon prilagodbe za dob i BMI), utvrđene su značajne razlike samo kod žena između tipova omjera prstiju desne ruke i broja zahvaćenih zglobova $(F=3.153, p=0043)$ i tipova omjera prstiju lijeve $(\mathrm{F}=3.330, \mathrm{p}=0.036)$ i desne $(\mathrm{F}=2.397, \mathrm{p}=0.047)$ ruke i ukupnih OA vrijednosti. Žene s omjerom tipa 3 imale su najviše prilagođene vrijednosti parametara OA šake. Rezultati jednosmjerne ANCOVA analize za tipove omjera duljine prsta desne ruke pokazali su značajnu razliku u OSS-u $(\mathrm{df}=2, \mathrm{~F}=7,569, \mathrm{P}=0,001)$, nakon prilagodbe za dob, spol i BMI. Posthoc usporedba pokazala je da su pojedinci s tipom $3(2 \mathrm{D}<4 \mathrm{D})$ pokazali značajno veće OSS vrijednosti od onih $\mathrm{s}$ tipom $1(\mathrm{p}=0,012)$ i tipom $2(\mathrm{p}=0,003)$. Analizom omjera duljine prsta lijeve ruke također je utvrđena značajna razlika u OSS vrijednostima ( $\mathrm{df}=2, \mathrm{~F}=3,290, \mathrm{P}=0,038$ ). Posthoc usporedba pokazala je da su osobe s omjerom tipa 3 pokazale značajno veće OSS vrijednosti od onih s omjerom tipa $2(\mathrm{p}=0,33)$. Otkrili smo da je niži omjer duljine prsta, vizualno ocijenjen muški tip omjera duljine prsta, povezan s kasnijom menarhom i kraćim reproduktivnim razdobljem. Nije nađena povezanost s dobi menopauze. Obiteljske korelacije omjera duljine prstiju nisu pokazale značajnu povezanost između bračnih partnera, međutim, nađene su značajne korelacije između roditelja i potomstva $(0,15-0,28, p<0,001)$ i između braće i sestara $(0,13-0,38, p<0,009)$. Heritabilnost (H2) vizualne klasifikacije omjera duljine prstiju bila je 0,36 za lijevu i 0,28 za desnu ruku; omjera prstiju 0,55 za lijevu i 0,66 za desnu ruku, a rendgenskih snimaka iznosila je 0,49 , odnosno 0,59 , što ukazuje na postojanje jasne obiteljske agregacije varijacija omjera duljine prstiju u čuvaškoj populaciji, koja se ne može objasniti samo uobičajenim utjecajima na okoliš. 
